\title{
Analiza instytucjonalna wspólnot z perspektywy społeczno-kulturowej tożsamości płci
}

\section{Zofia Łapniewska*}

\begin{abstract}
Streszczenie: Wspólnoty, społeczności czy kolektywy zespołowo zarządzają wspólnymi dobrami bez ingerencji zewnętrznych autorytetów, łącząc przy tym różne zasoby wiedzy oraz formy funkcjonowania. Ponieważ relacje płci wywierają wpływ na planowanie, produkcję, dobrostan oraz wiele innych aspektów życia, dlatego głębsze spojrzenie na założenia dotyczące dysponowania wspólnymi dobrami z tej perspektywy może pomóc wyeliminować uprzedzenia oraz zniekształcenia obecne w opracowaniach naukowych na ich temat.

Niniejszy artykuł ma charakter teoretyczny. Jego celem jest zilustrowanie możliwych sposobów i metod włączenia społeczno-kulturowego wymiaru płci w instytucjonalną analizę wspólnot i ich działań związanych z zarządzaniem wspólnymi dobrami. Przybliżono w nim znaczenie płci społeczno-kulturowej oraz społecznie tworzonych instytucji zarządzania wspólnymi dobrami. Jednocześnie, w oparciu o autorski model analizy instytucjonalnej oraz podane przykłady, wskazano na konieczność włączenia płci do badań nad tymi dobrami. Część ta stanowi unikalny wkład w dotychczasowe rozważania na ten temat. Naczelna konkluzja z przeprowadzonej dyskusji dotyczy potrzeby krytycznej refleksji badaczy, organizacji pozarządowych, jak i samych członków wspólnot nad rolą kobiet w tych grupach oraz tworzonymi przez wspólnoty instytucjami, które mogą wzmacniać bądź też przeciwdziałać nierównościom, tym samym mając kolosalny wpływ na osiągane przez nie wyniki.

Słowa kluczowe: dobra wspólne, gender, wspólnoty, analiza instytucjonalna, ekonomia feministyczna.
\end{abstract}

\section{Wprowadzenie}

Aktualnie wspólnoty zawiązują się zarówno wokółzasobów naturalnych (lasów, łowisk, systemów irygacyjnych, pastwisk, podziemnych zbiorników wodnych) czy innych dóbr fizycznych [Ostrom, 1965; Ostrom, 1990], jak i wokół miejsc i usług rozumianych jako „lokalne dobra wspólne" [Foster, 2011; Harvey, 2012] w przestrzeni miejskiej czy cyfrowej (np. ruch dotyczący wolnego oprogramowania) [Jeffrey, McFarlane, Vasudevan, 2012]. To zróżnicowanie otwiera pole do analiz zarządzania wspólnymi dobrami (ang. commons) oraz wspólnot jako przedmiotu i podmiotu badań. Jednym spośród wielu elementów ich analizy powinna być społeczno-kulturowa tożsamość płci (gender). Potrzeba włączenia perspektywy płci do tychże analiz wynika nie tylko z doświadczeń kobiet, które w wielu miejscach na świecie $w$ większym stopniu niż mężczyźni zależne są od dostępu do zasobów, ponoszą skutki ich prywatyzacji i są zaangażowane w ich obronę [Federici, 2004], lecz także z konieczności ujawnienia pełnego wkładu kobiet i mężczyzn w gospodarkę i społeczeństwo. Perspektywa ta ujęta w teoriach i modelach ekonomicznych przybliża tę dziedzinę do codziennego życia, pozwa-

\section{* Zofia Łapniewska} WiSE Research Centre Glasgow Caledonian University Cowcaddens Road, Glasgow G4 OBA, UK e-mail: z.lap@riseup.net 
lając zrozumieć wzory ludzkich zachowań podyktowanych zarówno świadomym wyborem, jak i zewnętrzną koniecznością. Jest to szczególnie ważne w kontekście zarządzania wspólnymi zasobami, jako że podobnie jak inne podmioty ekonomii społecznej - takie jak spółdzielnie [Bornstein, 2004; Michalik, 2011; Peredo, McLean, 2014] czy organizacje pozarządowe [Defourny, 2004; Bogacz-Wojtanowska, 2012] - wykraczają one poza zakorzeniony dualizm podziału na prywatne i publiczne. Tym samym, co znamienne dla celów i wartości ekonomii społecznej właśnie, stanowią one alternatywę dla dominujących form kapitalistycznego gospodarowania zorientowanego głównie na zysk.

Celem niniejszego artykułu jest wskazanie na istniejące intersekcje, a także konieczność włączenia społeczno-kulturowego wymiaru płci do instytucjonalnej analizy wspólnot wraz z zarządzanymi przez nie zasobami. Ma on charakter teoretyczny, lecz zilustrowany jest wieloma przykładami wskazującymi na szerokie korzyści płynące z uwzględnienia perspektywy płci w badaniach, jak i przy projektowaniu programów i projektów, z których miałyby korzystać wspólnoty. Przedstawiony w dalszej części niniejszego opracowania autorski model analizy instytucjonalnej wraz z przykładami empirycznymi wskazuje na konkretne miejsca teorii instytucjonalnej, które powinny uwzględniać wymiar gender, co stanowi nowy wkład do istniejących opracowań na jej temat.

\section{Asamblaż gender a wspólnoty}

Pojęcie gender, rozumiane jako społeczno-kulturowa tożsamość płci, stanowi konstrukcję przyporządkowania różnych ról, praw i szans osobom na podstawie ich płci biologicznej [Peterson, Lewis, 1999, s. 390396]. Procesy społeczne, ekonomiczne i kulturowe są naznaczone wzorem tych różnic i dominacji, które przejawiają się zarówno na poziomie percepcji, jak i materii, spycha- jąc kobiety na nieuprzywilejowane pozycje. $Z$ jednej strony jest to związane $z$ ich rolami produkcyjnymi i reprodukcyjnymi w rodzinie i społeczności, a z drugiej strony posiadają one znacznie mniej zasobów, które pozwoliłyby im na awans społeczny.

Gender to także relacje pomiędzy kobietami i mężczyznami we wspólnotach, podział pracy, dostęp do surowców, środków produkcji i ich kontrola, różne korzyści i potrzeby obu płci w lokalnej społeczności. Dlatego płeć jest integralną częścią wielu procesów społecznych i gospodarczych, włączając w to produkcję, dystrybucję i konsumpcję dóbr [Acker, 1992]. Zależności te mogą być analizowane na tle działań grupy w różnych wymiarach: tożsamości, seksualności, wzajemnych interakcji, kultury czy władzy [Lovenduski, 1998], wokół których powstają instytucje kształtujące relacje płci. Elinor Ostrom - pierwsza kobieta-laureatka Nagrody Nobla w dziedzinie ekonomii, która przez ponad 40 lat prowadziła badania teoretyczne i empiryczne nad wspólnotami wskazuje: "gdy kobiety aktywnie uczestniczą w tworzeniu zasad i mają wpływ na sposób funkcjonowania wspólnot, osiąga ona lepsze długoterminowe wyniki, których wartość jest znacznie wyższa" [May, Summerfield, 2012, s. 31]. Liczne badania i obserwacje terenowe potwierdziły także, że w społecznościach, w których nierówność płci była niewielka, występowała większa troska o przyszłe pokolenia, a zainteresowanie krótkoterminowymi zyskami było niższe [ibidem].

Analizy ekonomiczne uwzględniające perspektywę płci mają możliwość zmiany paradygmatu tej dyscypliny, nie tylko poprzez włączenie do niej tematów czerpiących z życia i doświadczeń kobiet, lecz także poprzez zbadanie roli, jaką odgrywa płeć w kształtowaniu wartości, które przyświecają tworzeniu założeń do badań i interpretacji wyników. Pozornie neutralne ze względu na płeć metodologie, koncepcje czy teorie mogą ukrywać, chronić i naturalizować przywileje płci [Peterson, Lewis, 1999, s. 390-396]. Przywileje te 
doskonale ilustruje zmiana znaczenia pracy na przełomie XVIII i XIX w., kiedy to rynek stał się głównym arbitrem wartości. Od tego czasu aktywności, których nie można było wycenić (np. prace wykonywane na rzecz gospodarstw domowych oraz prace opiekuńcze) przestały być postrzegane jako produktywne ekonomicznie. Ta nowa definicja pracy produktywnej zdeprecjonowała wkład gospodarczy kobiet, waloryzując jedynie prace rejestrowane i opłacane na rynku. Jednocześnie ten niewidoczny i nieopłacany wysiłek kobiet pomaga w łagodzeniu skutków oszczędnościowej polityki państwa, wpływając na lepsze zdrowie całych społeczności oraz ich wyższy dobrobyt [Elson, 1992].

Niemniej płeć nie jest jedynym wymiarem złożonej konstrukcji tożsamości. Hierarchia społeczna oraz różnice oparte na klasie, rasie, etniczności, wieku i seksualności determinują społeczną, kulturową i ekonomiczną pozycję osób w danej zbiorowości [Folbre, 1994]. Aspekty te powinny być uwzględnianie w opracowaniach i badaniach naukowych. Z uwagi jednak na ograniczoną objętość niniejszego artykułu, nacisk zostanie w nim położony głównie na społeczno-kulturową tożsamość płci.

\section{Zarządzanie wspólnymi dobrami}

Ostrom, podczas swojej pracy badawczej, obserwowała i poznawała lokalne aktorki i aktorów zależnych od ekosystemów w długim okresie czasu [Łapniewska, 2016]. Jej praca skupiona była na instytucjach, rozumianych jako prawidłowości ludzkich działań stanowionych i zmienianych przez:

- normy - uznane za nieformalne zwyczaje danej grupy czy społeczności, podzielane przez osoby do niej przynależące, które mają podobne wzajemne oczekiwania, cele i intencje; normy mogą dotyczyć np. sposobu witania się, a z ich (nie)przestrzeganiem związana jest (dez)aprobata,
- reguły - określające działania formalne podejmowane w wyniku konkretnej umowy pomiędzy stronami, związane z sankcjami stosowanymi w razie jej niedotrzymania, np. prawo do własności,

- konwencje - narzucone odgórnie zasady instytucjonalne takie jak np. język czy obowiązujący strój, których zastosowanie zależy często od pozycji jednostki w danej społeczności (tu indywidualne cechy takie jak płeć czy pochodzenie grają bardzo istotną rolę),

- wspólnie budowane strategie.

Powyższe elementy razem pozwalają wytworzyć mechanizmy umożliwiające rozwiązywanie konfliktów w grupie, zapobiegają dewastacji i wyczerpaniu wspólnego zasobu oraz powstrzymują zachowania rabunkowe [Hodgson 2006; Crawford, Ostrom, 1995; Vatn, 2005, s. 6-7].

Prowadzone przez Ostrom badania pozwoliły wysunąć tezę, że pomimo różnic między wspólnotami w zakresie celów działań, zasobów jakimi dysponują oraz ich atrybutów (reprezentacji, zasad użytkowania i struktur zarządzania), w powtarzających się sytuacjach określonych przez przyjęte instytucje, jednostki we wspólnotach współpracują na rzecz osiągania długoterminowych celów, takich jak produktywne wykorzystanie systemów zasobów naturalnych, czy czerpanie z nich kolektywnych korzyści (czyt. także Grodzicki [2015]). Tym samym obserwacje Ostrom doprowadziły do wniosku, że wspólnoty często efektywniej zapobiegają degradacji zasobów niż państwo, instytucje międzynarodowe czy prywatni właściciele [Ostrom, Gardner, Walker, 1992]. Stąd jej prace można czytać jako opozycję do założeń ekonomii głównego nurtu. Ten brak zewnętrznego "Lewiatana" (za Thomasem Hobbsem [1954]) jest tłumaczony w literaturze jako "osłabienie nadzoru” (ang. regulatory slippage) [Farber, 1999; Foster, 2011], gdy pewien poziom kontroli ze strony samorządu lub innej właścicielki bądź właściciela zasobu 
zostaje obniżony z różnych względów, włączając $w$ to świadome porzucenie danej przestrzeni (np. parku, placu, pola, budynku itd.) w wypadku wysokich kosztów jej utrzymania, monitorowania czy egzekwowania ograniczeń użytkowania [Foster, 2011, s. 66-70].

Teoria praw własności, rozwijana m.in. przez Elinor Ostrom [1990], Harolda Demsetza [1967], Garry'ego Libecapa [1989] i Daniela Bromleya [1991] wykracza poza dualizm państwowo-prywatny, wskazując na różnorodność typologii. Ostrom opisuje kategorie prywatnych dóbr (które mogą być również opuszczone i następnie skolektywizowane, bądź oddane do publicznego użytkowania przez właścicieli) i dóbr klubowych (ang. club goods/toll goods) jako wysoce wykluczających pod względem dostępu, w przeciwieństwie do dóbr publicznych i wspólnotowych [Ostrom, 1990]. Jednocześnie wskazuje ona, że dobra klubowe i wspólnotowe podlegają rywalizacji, podczas gdy nie ma to miejsca w przypadku dóbr prywatnych i publicznych o otwartym charakterze. Zgadza się ona z Garretem Hardinem [1968] co do twierdzenia, że zasoby ogólnodostępne, pozbawione zdefiniowanych użytkowników i właścicieli, są narażone na wyniszczenie w wyniku nadmiernej eksploatacji i przeludnienia. Jednakże stroni ona od wskazania na prywatyzację jako „jedyne” rozwiązanie. Tymczasem określa ona podstawowe instytucje, które przyjęte przez lokalne społeczności mogą pomóc im uniknąć „tragedii wspólnych zasobów" (ang. the tragedy of the commons) i stworzyć pulę dóbr trwałych w długim okresie czasu, bez konieczności przeniesienia praw własności w prywatne ręce.

Pierwsza z nich - jasno zdefiniowane granice zasobu - odpowiada na wyniszczenie dóbr o otwartym charakterze opisane przez Hardina. Granice te mogą np. dotyczyć fragmentu lasu przeznaczonego do wspólnego użytkowania czy łowiska wykorzystywanego jedynie przez członków wspólnoty. Społeczność ta reguluje skalę użycia zasobu, sposób eksploatacji oraz wyznacza aktorki i aktorów, którzy czerpią z niego korzyść. Tym samym może ona zakazać wstępu osobom z zewnątrz oraz nałożyć sankcje na jednostki łamiące ustalone zasady. Działanie kolektywne ułatwia bliska lokalizacja zasobu oraz wysoka zależność mieszkańców od jego zdolności do odtwarzania się i trwania.

Pozostałe instytucje obejmują przyjęcie wartości wspólnego podejmowania decyzji, przystosowanie środków oraz zaopatrzenia do warunków lokalnych, stworzenie zasad monitoringu i ustalenie uprzednio wskazanych sankcji, określenie mechanizmów rozwiązywania konfliktów oraz posiadanie praw do zrzeszania się i organizacji [Ostrom, 1990, s. 88-102]. Zasady te pomagają w utrzymaniu zasobu w długim okresie czasu, a towarzyszące im instytucje pozwalają zrozumieć, dlaczego aktorki i aktorzy lokalni włączają się w ustalenie szczegółowych działań operacyjnych, przestrzeganie przyjętych norm, monitorowanie korzystania ze wspólnego dobra i przekazywanie wypracowanych porozumień kolejnym pokoleniom.

Kolektywne działania są podejmowane zazwyczaj, gdy wszystkie osoby z grupy mogą czerpać materialne i niematerialne korzyści ze współpracy. Tym samym mogą oni np. wspólnie inwestować, dbać o lokalną infrastrukturę czy zajmować się promocją wspólnoty na zewnątrz. Za każdym razem jednak wyniki współpracy zależą od kilku czynników takich jak: wielkość grupy, podzielane wartości, wcześniejsze sukcesy we wspólnych przedsięwzięciach, skuteczne przywództwo (hierarchiczne albo niehierarchiczne) lub inne posiadane środki i zależności pomiędzy osobami we wspólnocie [Agarwal, 2001; Ostrom, 1990, s. 188].

Ludzie tworzący wspólnoty przeważnie kierują się innymi wartościami niż racjonalność homo oeconomicusa [Persky, 1995]. Dlatego dziś, po doświadczeniach światowego kryzysu finansowego, a także przed kolejnym kryzysem, który nas czeka w kolejnej deka- 
dzie, wspólnoty mogą być postrzegane jako strona podwójnego ruchu opisanego przez Karla Polanyi'ego [1957]. Chronią one społeczności przed eksploatacją, alienacją i migracją, skutecznie opierając się prywatyzacji, urynkowieniu i uprzedmiotowieniu [Polanyi, 1957, s. 130; Hardt, Negri, 2009, s. 124]. Nabiera to szczególnego znaczenia w miastach, gdyż sprzeciw wobec kapitalizmu ostatnich dwóch stuleci miał właśnie charakter miejski [Castells, 1983]. Stąd miejskie wspólnoty, będące przykładem alternatywnego modelu organizacji społecznej, mogą stanowić potencjał dla szerszych zmian instytucjonalnych w odniesieniu do dzielonej przez mieszkańców przestrzeni oraz usług [Łapniewska, 2015]. Rosnąca liczba wspólnot zawiązywanych na całym świecie, $z$ ich różnorodnością wskazuje, że ich rola nie może być niedoceniona lub pominięta, zaś liczne wskazania na atuty wspólnej własności otwierają nową przestrzeń do dyskusji nad efektywnym zarządzaniem licznymi zasobami w sposób kolektywny i partycypacyjny, poza dychotomią podziału na państwowe i prywatne.

Niestety projekty społeczne oraz inicjatywy oddolne nie zawsze uwzględniają perspektywę płci, często wzmacniając lokalną patriarchalną kontrolę elit, skutkującą m.in. nierównym udziałem wszystkich osób w kolektywnym przedsięwzięciu i dysproporcjonalnym podziałem korzyści [Porter, Judd, 1999]. Niektóre modele współpracy mylnie zakładają, że interesy poszczególnych osób w grupie są jednakowe, a ich udział przynosi takie same korzyści wszystkim członkiniom i członkom wspólnoty [Momsen, 2002]. Pomimo iż instytucjonaliści proponują alternatywną formułę zarządzania wspólnymi zasobami, w niewielkim stopniu odnoszą się oni w swoich opracowaniach do wpływu tych działań na kobiety i mężczyzn.

Ostrom oraz inne badaczki i badacze przestrzegają także przed nadmiernym optymizmem dotyczącym samoorganizacji wspólnot. Pomimo iż w wielu miejscach na świecie członkinie i członkowie grupy razem ustanawiają instytucje i potrafią skutecznie zarządzać dzielonym zasobem, w niektórych przypadkach nie jest to możliwe. W takich sytuacjach rządowe/samorządowe albo prywatne porozumienia/kontrakty okazują się bardziej skuteczne. Wiele zależy również od zaadoptowania specyficznej kompozycji instytucjonalnej do lokalnej kultury oraz od sposobów jej wdrożenia. Literatura studiów nad rozwojem wskazuje na liczne przykłady programów, które były skupione na aktywnym uczestnictwie kobiet, ale nie zdołały osiągnąć celów związanych z efektywnością bądź wzmocnieniem pozycji kobiet. Wiązało się to przede wszystkim z brakiem wiedzy na temat struktury grupy oraz panujących w niej nieformalnych zasad, co udaremniło adekwatne dotarcie tych programów do członkiń wspólnoty [Mayoux, 1995]. Przykłady można znaleźć również wśród działań grup samopomocowych dla kobiet inicjowanych z zewnątrz, które nie zajmując się męskością oraz nie podejmując tematu uczestnictwa mężczyzn w tych grupach, straciły potencjalną szansę na rozwój procesów na rzecz zmiany w kolektywnym działaniu [Cornwall, 2000].

Tym samym wspólnie realizowane programy, które nie uwzględniają perspektywy gender albo traktują kobiety instrumentalnie, jako beneficjentki, bez głębszego zrozumienia relacji płci w danej społeczności, niosą ryzyko dalszego osłabienia pozycji kobiet we wspólnocie. Z drugiej strony nastawienie jedynie na osiągnięcie równości płci w miejsce postrzegania jej jako drogi do osiągnięcia celów grupy może dać efekty odwrotne do zamierzonych. Stąd tak ważne jest zrozumienie wpływu działań wspólnotowych na równość płci, które może pomóc wybrać strategię w najwyższym stopniu stymulującą proces zmiany na rzecz równości na poziomach mikro-, mezo- i makro.

Teorie dotyczące wspólnot dodatkowo stoją przez trzema wyzwaniami: 
- powinny one uwzględnić stopniową, samo-przekształcającą się naturę zmiany instytucjonalnej,

- podkreślać wagę wpływu zewnętrznego reżimu politycznego na analizę zależności między wewnętrznymi zmiennymi a warunkami wspólnie przyjmowanych przez wspólnoty zasad na różnych poziomach działania,

- uwzględniać wagę informacji i koszty transakcji [Ostrom, 1990, s. 191].

Próby odpowiedzi na powyższe wyzwania trwają od początku lat 90., jednak wiele czynników determinujących instytucje pozostaje nieuchwytna, podlega ciągłym zmianom, jest trudna w rejestracji i przez to nadal pomijana w testowaniu i rozwijaniu nowych teorii. Dodatkowo wspólnoty na całym świecie znacznie się od siebie różnią, dlatego wśród metod badawczych dominują studia przypadku, a uniwersalne wnioski formułowane są niezwykle rzadko.

Choć analizy instytucjonalne, zarówno prowadzone przez Ostrom, jak i innych badaczy, wykraczały poza dokonywane przez społeczności transakcje związane z zarzadzaniem wspólnymi dobrami i poruszały kwestie dylematów społecznych drugiego rzędu (np. stopień współpracy osób w grupie czy wymierzanie kar za odstępstwa od ustalonych reguł), z uwagi na ograniczoną objętość niniejszego artykułu, skoncentrowany on będzie na wyjściowej analizie instytucjonalnej wspólnot z perspektywy gender, która zostanie przedstawiona poniżej.

\section{Gender w ramach analizy instytucjonalnej wspólnot}

Zdefiniowanie instytucji oraz zrozumienie procesu zmiany instytucjonalnej to kluczowe elementy poznania ekonomicznej, społecznej i ekologicznej roli wspólnot, umożliwiające dostrzeżenie złożonych relacji między aktorkami i aktorami, którzy dokonują transakcji na arenie wydarzeń [Ostrom, 1998; Hagedorn,
Arzt, Peters, 2002]. Literatura dotycząca procesów tworzenia norm, reguł czy konwencji, a także samej zmiany instytucjonalnej jest bardzo obszerna (patrz - porównanie podejść teoretycznych opisanych przez Christophera Kingston'a i Gonzalo Caballero [2009]) i może stanowić temat kolejnego artykułu wskazującego na istotę włączenia perspektywy płci w te procesy. Tymczasem, naszkicowany przez autorkę model, przedstawiony na rysunku 1, może posłużyć jako punkt wyjścia do dalszych pogłębionych badań nad złożonymi interakcjami między ludźmi, które łączyłyby kolektywne działania z gender. Na podstawie trzech teorii dotyczących analizy instytucjonalnej wspólnot przedstawionych przez: Elinor Ostrom [2005, s. 15] - Ram Analizy Instytucjonalnej i Rozwoju (ang. Institutional Analysis and Development (IAD) Framework), Konrada Hagedorna [2008] - Instytucji Zrównoważenia (ang. Institutions of Stability (loS)), oraz Fritza W. Scharpfa [1997, s. 44] - Instytucjonalizmu Skoncentrowanego na Aktorach (ang. Actor-Centered Institutionalism), powstał schemat łączący te trzy podejścia, wskazujący na kluczowe elementy badań wspólnot, ich otoczenia instytucjonalnego oraz podejmowanych działań z perspektywy płci.

Poniższy model, podobnie jak teorie Ostrom, Hagedorna i Scharpfa, umieszcza aktorki i aktorów w absolutnym centrum rozważań, wraz z ich indywidualnymi cechami, takimi jak: wiek, klasa, pochodzenie etniczne, rasa, niepełnosprawność, orientacja psychoseksualna czy właśnie tożsamość płciowa. Wyznaczają one osobom początkową pozycję w sieciach społecznych, tym samym różnicując wyjściowy poziom kapitału społecznego, który z jednej strony ma istotny wpływ na interakcje danej osoby z innymi ludźmi (i tym samym na wyniki przeprowadzanych transakcji), a z drugiej na kształtowanie otoczenia instytucjonalnego (omówione wpływy obrazują poziome strzałki diagramu). To aktorki i aktorzy tworzą instytucje, dlatego ich pozycja we wspólnocie jest tak ważna. Jednocze- 
śnie wstępna identyfikacja i charakterystyka tychże instytucji stanowi podstawę do ich dalszych obserwacji i pomiaru.

Otoczenie instytucjonalne, przedstawione po lewej stronie diagramu, składa się z trzech elementów, które razem stanowią pewną społeczną kondycję, zaplecze instytucjonalne do podejmowania działań i decyzji przez aktorki i aktorów na arenie wydarzeń. Instytucje (wewnętrzne i zewnętrzne) i struktury zarządzania (np. kontrakty, sieci, rozwiąza- nia biurokratyczne, współpraca lub rynek) są środkami organizacyjnymi wpływającymi na skuteczność tychże działań. Powstają one spontanicznie bądź też w wyniku samoorganizacji danej społeczności [Hagedorn, 2008, s. 359-360]. Struktury zarządzania mogą dotyczyć organizacji pracy i środków np. do nawodnienia wspólnego pola, jak również do ustalenia zasad i ograniczeń jego wspólnego użytkowania.

\section{Rysunek 1. Ramy analizy instytucjonalnej}

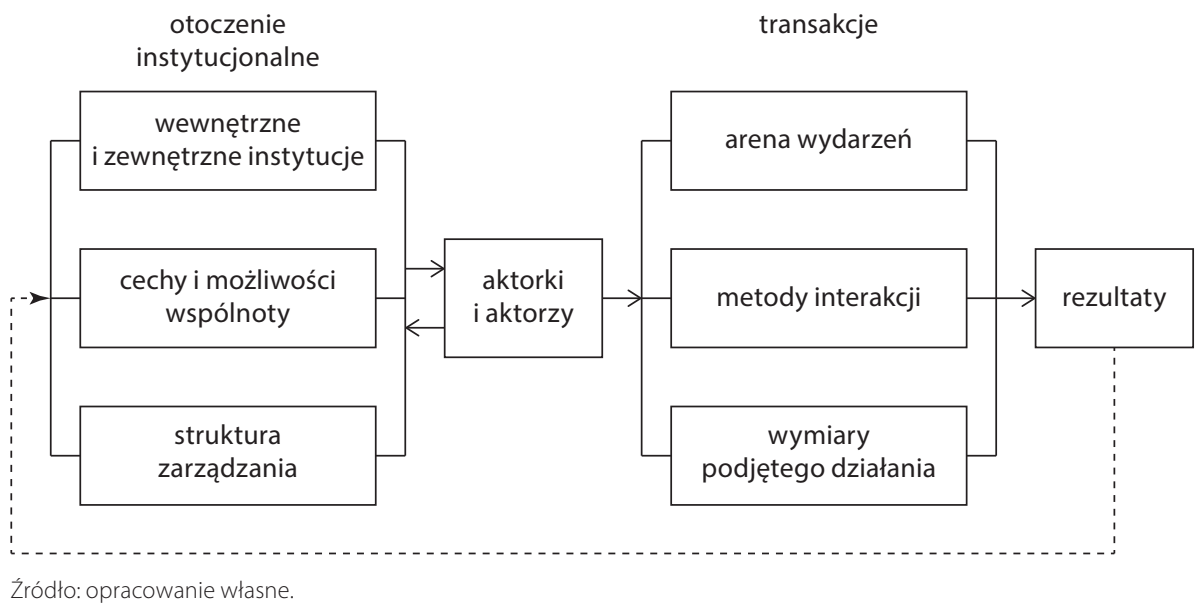

Kolektywne działania mogą być wzmacniane lub uzupełniane zewnętrznymi regulacjami prawnymi (zewnętrzne instytucje i możliwości wspólnoty), ale bardzo często struktury zarządzania determinuje prawo zwyczajowe danej społeczności (cechy wspólnoty). Prawo to nie zmienia się z dnia na dzień, a w dużym stopniu kształtuje ono normy funkcjonowania obu płci, wpływając na relacje władzy i skutkując progresywną albo regresywną polityką, wzmacniającą albo osłabiającą pozycję kobiet we wspólnocie. Przykładowo, członkinie i członkowie grupy mogą zakładać, że kobiety nie posiadają wystarczającej wiedzy oraz umiejętności, aby w pełni partycypować w kolektywnych działaniach. Bina Agarwal [2001] zauwa- żyła, że w lokalnych programach zalesiania w Indiach i Nepalu kobiety były postrzegane jako osoby, które mają niewiele do powiedzenia w kwestiach ochrony lasów i w związku z tym rzadko były zapraszane na spotkania społeczności lokalnej. W wielu sytuacjach kobiety i mężczyźni wręcz podzielali przekonanie, że na zebraniach nie ma przestrzeni na komentarze kobiet. Stąd onieśmielone bądź też zastraszone kobiety zajmowały miejsca w tyle sali lub na podłodze, jedynie obserwując przebieg wydarzeń. Z drugiej strony, to właśnie kobiety często stoją na czele ruchów ochrony środowiska naturalnego i bioróżnorodności np. znana z protestów przeciwko opatentowaniu nasion Vandana Shiva [Klein, 2015, s. 285], dlatego dostrzeżenie i docenie- 
nie ich działań w tym zakresie może być kluczowe dla powodzenia lokalnej społeczności.

Szanse kobiet i mężczyzn na włączenie się w działania kolektywne zdeterminowane są także takimi cechami i możliwościami wspólnoty jak stopień ich wrażliwości na ekonomiczne, społeczno-polityczne i naturalne wstrząsy, których odczuwanie może się różnić w zależności od przyjętych norm i konwencji w odniesieniu do płci społeczno-kulturowej. Badania przeprowadzone w Indiach wykazały, że kobiety i dziewczynki częściej niż męska strona rodziny cierpią na niedożywienie w obliczu sezonowego niedoboru żywności [Behrman, Deolalikar, 1990]. Zewnętrzne wstrząsy nie są jednak jedynymi przesłankami ograniczenia aktywności kobiet. Wiele zależy od stopnia podporządkowania kobiet męskim członkom rodziny, którzy mogą nie wyrazić zgody na zaangażowanie, podejmowanie decyzji oraz czerpanie korzyści przezżony/matki/ córki/partnerki ze wspólnotowego działania. Tym samym płeć społeczno-kulturowa jest ważnym czynnikiem warunkującym podział praw, zasobów, odpowiedzialności i pracy w gospodarstwie domowym (którą obarczane są głównie kobiety), jak i poza nim [Alderman i inni, 1995]. W Bangladeszu jedna z organizacji pozarządowych próbowała stworzyć jedynie kobiece komitety zarządzające zasobami wodnymi. Niestety starania, aby zaangażować kobiety w długim okresie czasu zawiodły w muzułmańskiej społeczności, ponieważ organizacja ta niedostatecznie rozumiała lokalny podział ról przypisanych płci [Sultana, Thompson, 2006].

Aktorki i aktorzy na rysunku 1 dokonują transakcji, które uwzględniają kapitał społeczny, polityczny, ludzki, fizyczny, naturalny, informacyjny, finansowy, oraz prawny - związany z prawem do własności określonego zasobu. Termin „transakcje” w ekonomii instytucjonalnej obejmuje aktywności związane z przemianą dobra lub usługi na płaszczyźnie technologicznej (wymagające koordynacji), lub jako transferu praw własności [Beckmann,
2000]. Ilustrację transakcji może stanowić tu przykład kobiet zbierających drewno na opał na określonym terytorium. Mają one do niego dostęp, ale nie mają prawa do sadzenia na nim drzew. Działalność ta jest wyłącznie zarezerwowana dla właścicieli ziemi. Dlatego prawa kobiet do własności są istotne nie tylko z punktu widzenia produktywności zasobu, ale także wzmocnienia pozycji kobiet oraz podniesienia standardu życia członkiń i członków gospodarstwa domowego. Liczne badania wskazują, że posiadane przez kobiety prawa do własności przekładają się na ich status w rodzinie i społeczności, dzięki czemu zyskują one lepszą pozycję w negocjacjach [Quisumbing, 2003]. W ramach działań kolektywnych często warunkiem uczestnictwa w grupie jest właśnie wyposażenie w aktywa (niekoniecznie materialne) cenione przez daną wspólnotę.

Założenia dotyczące areny kolektywnych działań, takie jak omówione powyżej wyposażenie w środki trwałe, wiedzę i umiejętności, systemy prawne i ekonomiczne, bezsprzecznie oddziałują na wyniki osiągane przez wspólnoty. Arena ta stanowi również miejsce do negocjacji społecznych. Gdy zostaje uwzględniona przez nią perspektywa gender, widoczne stają się różnice w doświadczaniu warunków funkcjonowania w grupie przez kobiety i mężczyzn, tym samym ich odmienne motywacje i zdolności do wspólnej pracy. Struktura płci wspólnot ma znaczenie w kontekście efektywności realizowanych przez nie przedsięwzięć, a kolektywna praca wpływa na wyrównywanie szans i wzmocnienie pozycji kobiet [Pandolfelli, Meinzen-Dick, Dohrn, 1998]. Ruth Meinzen-Dick i Margreet Zwarteveen [1998] zaobserwowały, że włączenie kobiet do organizacji zajmujących się zasobami wodnymi w Azji Południowej wzmocniło skuteczność zarządzania systemami irygacyjnymi. Dodatkowo ich obecność miała pozytywny wpływ na zwalczanie ubóstwa i nierówności płci, szczególnie gdy wspólne działania owo- 
cowały wyrównanym podziałem zasobów, który wpływał z kolei na podniesienie jakości życia mieszkanek i mieszkańców, a szczególnie osób z grup marginalizowanych. Z kolei prowadzone przez Olafa Westermanna, Jacqueline Ashby i Jules Pretty badania nad zarządzaniem zasobami naturalnymi w 33 programach wiejskich w 20 krajach Ameryki Łacińskiej, Afryki i Azji pozwoliły wyciągnąć wniosek, że współpraca, rozwiązywanie konfliktów oraz solidarność wewnątrz grupy rośnie, gdy kobiety są jej członkiniami [Westermann, Ashby, Pretty, 2005]. Powyższe rezultaty w wielu miejscach na świecie pozytywnie wpływają na zmianę instytucji takich jak normy, reguły i konwencje, wyrównując szanse kobiet i mężczyzn nie tylko w opisywanych tu społecznościach (sprzężenie zwrotne zilustrowane przerywaną strzałką na rysunku 1), lecz także inspirując aktywistów i badaczy do nadania wysokiego priorytetu wymiarowi płci przy prowadzeniu projektów i programów na rzecz wspólnot i analizie zachodzących zmian instytucjonalnych. Jak wykazano powyżej, często od tej jednej charakterystyki - społeczno-kulturowej tożsamości płci - zależy powodzenie wielu przedsięwzięć, dlatego - na co wskazały podane przykłady - jej uwzględnienie jest kluczowe w obecnych i przyszłych badaniach nad społecznościami i ich działaniami.

\section{Podsumowanie}

Celem niniejszego artykułu było przedstawienie możliwych sposobów włączenia społeczno-kulturowego wymiaru płci w instytucjonalną analizę wspólnot i działań związanych z zarządzaniem wspólnymi dobrami. W pierwszej części wskazano na znaczenie płci społeczno-kulturowej oraz społecznie tworzonych instytucji zarządzania dzielonymi zasobami. Kolejno przedstawiono założenia teoretyczne dotyczące badań wspólnot pod kątem gender, odpowiadający tym założeniom model analizy instytucjo- nalnej, poparty przykładami empirycznymi wskazującymi na konkretne miejsca odniesienia teorii do społeczno-kulturowego wymiaru płci. Argumentacja uporządkowana wedle zaprezentowanego modelu, wskazała na potrzebę włączenia perspektywy płci do badań - aktorek i aktorów wspólnot, elementów ich otoczenia instytucjonalnego (tworzonych instytucji, cech i możliwości działań, oraz struktur zarządzania), a także przeprowadzanych przez te osoby transakcji na arenie wydarzeń - z uwagi na wyjątkowe znaczenie tej cechy tożsamości społecznej dla osiąganych przez wspólnotę wyników. Oprócz ukazania superlatyw z włączenia perspektywy gender do analizy wspólnot, publikacja ta odniosła się także do zagrożeń, które wynikają z nieuwzględnienia lub błędnego zrozumienia roli płci w działaniach kolektywnych. Jednocześnie należy nadmienić, że przedstawione w tym artykule uzasadnienie nie wyczerpuje tematu analizy instytucjonalnej wspólnot z perspektywy płci. Każdy element przedstawionego modelu może stanowić przedmiot odrębnych studiów i analiz, w których niezwykle pomocne mogą okazać się prace antropologów, socjologów, geografów społecznych, politologów czy ekonomistów nurtów heterodoksyjnych. Jak już wcześniej wspomniano, instytucjonalizm wykracza także poza przedstawione ramy transakcji i uwzględnia m.in. rolę porządków formalnych wyższego rzędu (np. prawo, czy wymagania kapitalistycznych rynków pracy - także nieobojętnych na społeczny wymiar płci), które wraz z wymienionymi uprzednio procesami zmian instytucjonalnych mogą stać się przedmiotami dalszych dociekań dotyczących wspólnot z perspektywy gender. Same społeczności, które dziś zawiązują się zarówno w miastach, jak i na terenach niezurbanizowanych, mogą również czerpać z bogatego dorobku myśli i rozwiązań ekonomii społecznej [patrz Hausner, 2007; Defourny, Nyssens, 2010], oraz teorii i praktyk opisanych przez naukowców, stanowiących literaturę 
niniejszego artykułu. Tym samym jego autorka wyraża nadzieję, że zachęci on do zgłębiania teorii wspólnot zarówno polskie badaczki i badaczy społecznych, jak i praktyczki oraz praktyków na co dzień podejmujących działania kolektywne w swoim najbliższym otoczeniu.

\section{Literatura}

Acker J. (1992). "Gendered Institutions. From Sex Roles to Gendered Institutions", Contemporary Sociology, nr 21(5), s. 565-569.

Agarwal B. (2001). „Participatory Exclusions, Community Forestry, and Gender: An Analysis for South Asia and a Conceptual Framework", World Development, nr 29(10), s. 1623-1648.

Alderman H., Chiappori P-A., Haddad L., Hoddinott J., Kanbur R. (1995). „Unitary versus collective models of the household: Is it time to shift the burden of proof?", World Bank Research Observer, nr 10(1), s. 1-19.

Beckmann V. (2000). Transaktionskosten und Institutionelle Wahl in der Landwirtschaft. Zwischen Markt, Hierarchie und Kooperation. Berlin: Edition Sigma.

Behrman J. R., Deolalikar A.B. (1990). "The IntraHousehold Demand for Nutrients in Rural South India: Individual Estimates, Fixed Effects and Permanent Income", Journal of Human Resources, nr 24(4), s. 655-96.

Bogacz-Wojtanowska E. (2012). „Problemy organizacji pozarządowych przekształcających się w podmioty ekonomii społecznej", Ekonomia Społeczna, nr 1, s. 33-42.

Bornstein D. (2004). How to Change the World. Social Entrepreneurs and the Power of New Ideas. Oxford: Oxford University Press.

Bromely D.W. (1991). Environment and Economy: Property Rights and Public Policy. Oxford: Blackwell Publishing.

Castells M. (1983). The City and the Grassroots: A Crosscultural Theory of Urban Social Movements. Berkeley: University of California Press.

Cornwall A. (2000). „Missing Men? Reflections on Men, Masculinities and Gender in GAD", IDS Bulletin, nr 3(2).

Crawford S.E., Ostrom E. (1995). „A Grammar of Institutions", The American Political Science Review, nr 89(3), s. 582-600.

Defourny J. (2004). "From Third Sector to Social Enterprise", w: C. Borzaga, J. Defourny (red.), The Emergence of Social Enterprise. Londyn: Routledge, s. 1-18.

\section{Podziękowania}

Dziękuję prof. Bożenie Chołuj za zmotywowanie mnie do napisania tego artykułu oraz dwóm anonimowym recenzentom, których uwagi pozwoliły mi udoskonalić ten manuskrypt. Jego powstanie było możliwe dzięki stypendium Fundacji Fritza Thyssena [grant nr Az. 40.13.0.008].

Defourny J., Nyssens M. (2010). "Conceptions of Social Enterprise and Social Entrepreneurship in Europe and the United States: Convergences and Divergences", Journal of Social Entrepreneurship, nr 1 (1), s. 32-53.

Demsetz H. (1967). "Toward a Theory of Property Rights", American Economic Review, nr 57, s. 347-359.

Elson D. (1992). "From Survival Strategies to Transformation Strategies: Women's Needs and Structural Adjustment", w: J. Beneria, S. Feldman (red.), Unequal Burden: Economic Crises, Persistent Poverty and Women's Work. Boulder: Westview Press, s. 26-48.

Farber D.A. (1999). "Taking Slippage Seriously: Noncompliance and Creative Compliance in Environmental Law", Harvard Environmental Law Review, nr 23, s. 297-325.

Federici S. (2004). Caliban and the Witch: Women, The Body, and Primitive Accumulation. Nowy Jork: Autonomedia Brooklyn.

Flobre N. (1994). Who pays for the kids: gender and the structures of constraint. Londyn: Routledge.

Foster S.R. (2011). "Collective Action and the Urban Commons", Notre Dame Law Review, nr 87(1), s. 57-134.

Grodzicki M. (2015). „Dlaczego grupom udaje się podejmować działania? Przedstawienie teorii działań zbiorowych Elinor Ostrom", Ekonomia Społeczna, nr 1/2015, s. 66-78.

Hagedorn K. (2008). "Particular requirements for institutional analysis in nature-related sectors", European Review of Agricultural Economics, nr 35 (3), s. 357-384.

Hagedorn K., Arzt K., Peters U. (2002). ,Institutional Arrangements for Environmental Co-operatives: a Conceptual Framework", w: K. Hagedorn (red.), Environmental Cooperation and Institutional Change. Theories and Policies for European Agriculture. Cheltenham: Edward Elgar, s. 3-22.

Hardin G. (1968). "The Tragedy of the Commons", Science, $\mathrm{nr} 162$, s. 1243-1248.

Hardt M., Negri A. (2009). Commonwealth. Cambridge: The Belknap Press.

Harvey D. (2012). Rebel Cities. From the Right to the City to the Urban Revolution. Londyn: Verso.

Hausner J. (2007). „Ekonomia społeczna jako sektor gospodarki", Ekonomia Społeczna, nr 1, s. 9-14. 
Hobbes T. (1992). Lewiatan czyli Materia, forma i władza państwa kościelnego i świeckiego, tłum. Czesław Znamierowski. Warszawa: Państwowe Wydawnictwo Naukowe.

Hodgson G.M. (2006). "What Are Institutions”, Journal of Economic Issues, nr 40 (1), s. 1-25.

Jeffrey A., McFarlane C., Vasudevan A. (2012). „Rethinking Enclosure: Space, Subjectivity and the Commons", Antipode, nr 44(4), s. 1247-1267.

Kingston Ch., Caballero G. (2009). "Comparing Theories of Institutional Change", Journal of Institutional Economics, nr 5(2), s. 151-180.

Klein N. (2015). This Changes Everything. Capitalism vs. The Climate. Londyn: Simon \& Schuster.

Libecap G.D. (1989). Contracting for Property Rights. Cambridge: Cambridge University Press.

Lovenduski J. (1998). "Gendering Research in Political Science", Annual Review of Political Science, nr 1, s. 333-356.

Łapniewska Z. (2015). „(Re)claiming Space by Urban Commons", Review of Radical Political Economics, DOI: 10.1177/0486613415616217

Łapniewska Z. (2016). "Reading Elinor Ostrom through a Gender Perspective", Feminist Economics, nr 22(4), s. 129-151.

May A. M., Summerfield G. (2012). „Creating a Space where Gender Matters: Elinor Ostrom (1933-2012) talks with Ann Mari May and Gale Summerfield", Feminist Economics, nr 18(4), s. 25-37.

Mayoux L. (1995). „Beyond Naivety: Women, Gender Inequality and Participatory Development", Development and Change, nr 26(2), s. 235-258.

Meinzen-Dick R., Zwarteveen M. (1998). "Gendered Participation in Water Management: Issues and Illustrations from Water Users' Associations in South Asia", Agriculture and Human Values, nr 15(4), s. 337-345.

Michalik A. (2011). „Spółdzielnia socjalna jako platforma wymiany doświadczeń i podnoszenia kompetencji zawodowych", Ekonomia Społeczna, nr 1, s. $29-40$.

Momsen J. (2002). „NGOs, Gender and Indigenous Grassroots Development", Journal of Development Studies, nr 14, s. 1-9.

Ostrom E. (1965). Public Enterpreneurship: A Case Study in Ground Water Management, rozprawa doktorska. Los Angeles: University of California.

Ostrom E. (1990). Governing the Commons. The Evolution of Institutions for Collective Action. Cambridge: Cambridge University Press.
Ostrom E. (1998). "The Institutional Analysis and Development Approach", w: E. Loehman Tusak, D. M. Kilgour (red.), Designing Institutions for Environmental and Resource Management. Cheltenham: Edward Elgar, s. 68-90.

Ostrom E. (2005). Understanding Institutional Diversity. New Jersey: Princeton University Press.

Ostrom E. (2009). „A General Framework for Analyzing Sustainability of Social-Ecological Systems", Science, $\mathrm{nr}$ 325, s. 419-422.

Ostrom E., Gardner R., Walker J. (1992). „Covenants With and Without a Sword: Self-Governance is Possible", The American Political Science Review, nr 86(2), s. 404-417.

Pandolfelli L., Meinzen-Dick R., Dohrn S. (2007). "Gender and Collective Action: A Conceptual Framework for Analysis", CAPRi Working Paper, nr 64. Washington: International Food Policy Research Institute.

Peredo A. M., McLean M. (2014). „Przedsiębiorczość społeczna: krytyczny przegląd koncepcji", tłum. R. Śmietana, Ekonomia Społeczna, nr 1, s. 77-89.

Persky J. (1995). „Retrospectives: The Ethology of Homo Economicus", The Journal of Economic Perspectives, nr 9(2), s. 221-231.

Peterson J., Lewis M. (1999). The Elgar Companion to Feminist Economics. Cheltenham: Edward Elgar.

Polanyi K. (1957). The Great Transformation. Boston: Beacon Press.

Porter M., Judd E. (red.) (1999). Feminists Doing Development. Nowy Jork: Zed Books.

Quisumbing A.R. (red.) (2003). Household Decision, Gender, and Development: A Synthesis of Recent Research. Washington: International Food Policy Research Institute.

Scharpf F.W. (1997). Games Real Actors Play. Actorcentered Institutionalism in Policy Research. Boulder: Westview Press.

Sultana P., Thompson P. (2006). "Gender and local floodplain management institutions - A case study from Bangladesh", CAPRi Working Paper, nr 57. Waszyngton: International Food Policy Research Institute.

Vatn A. (2005). Institutions and the Environment. Cheltenham: Edward Elgar.

Westermann O., Ashby J., Pretty J. (2005). "Gender and social capital: the importance of gender differences for the maturity and effectiveness of natural resource management groups", World Development, nr 33(11), s. 1783-1799.

\section{A Gender-centered Perspective in the Institutional Analysis of Commons}

Summary: People of communities, local societies or collectives work together to manage common-pooled resources (commons) without an external authority by combining multiple knowledge sources and ways of functioning. Since gender relations affect planning, production, well-being, and many other aspects of life, an in-depth look into the assumptions about commons might help avoid bias and distortion in disciplinary accounts. 
This theoretical paper aims to present various ways and methods of including gender in the institutional analysis of communities and their actions related to the governing of commons. Therefore, it challenges gender relations within communities and introduces the meaning of socially-constructed institutions in the governing of common resources. Further, relying on my framework of institutional analysis and the given examples, I address the necessity of the inclusion of gender-centred perspective in deliberations on commons. This part provides a unique contribution to the studies on that subject. The main conclusion of this analysis is the need for a critical reflection of researchers, non-governmental organisations and members of communities on their institutions which can enhance or combat inequalities, thereby significantly impacting the achieved results.

Keywords: commons, gender, communities, institutional analysis, feminist economics.

\section{Prawa autorskie i licencja / Copyright and License}

Artykuł opublikowano na licencji Creative Commons

Uznanie autorstwa - Użycie niekomercyjne - Bez utworów zależnych 3.0 Polska

http://creativecommons.org/licenses/by-nc-nd/3.0/pl/

This article is published under the terms of the Creative Commons Attribution - NonCommercial - NoDerivs (CC BY-NC-ND 3.0) License

http://creativecommons.org/licenses/by-nc-nd/3.0/ 